\title{
АКСІОЛОГІЧНИЙ ПІДХІД ДО ФОРМУВАННЯ ПРОФЕСІЙНОЇ КОМПЕТЕНТНОСТІ В МАЙБУТНІХ ФАХІВЦІВ
}

\section{Гринюк С. П., Желуденко М. О.}

\section{ВСТУП}

В умовах сучасної цивілізації пошук і визначення цінностей як однієї 3 найважливіших основ для розбудови громадянського суспільства країни набули широкої популярності, оскільки саме цінності $\epsilon$ тими орієнтирами в навколишньому середовищі, які визначають вибір цілі, норми поведінки, зміст; спрямовують вектор розвитку суспільства та відображають образ бажаного майбутнього. Саме тому в Законах України «Про освіту», «Про вищу освіту», Національній доктрині розвитку освіти, Концепції розвитку освіти до 2025 року наголошується на культуроцентричності, збереженні й примноженні національних виховних традицій, розвитку творчої особистості, гуманізації освіти ${ }^{1}{ }^{2}$.

Одним із головних завдань закладу вищої освіти сьогодні є важливість формування ціннісних орієнтацій в етичному, загальнокультурному, професійному рівнях. У світлі цього проблема аксіологічного підходу, який проголошує людину найвищою цінністю суспільства й самоціллю суспільного розвитку та дає змогу досліджувати явища з погляду закладених у них можливостей задоволення потреб особистості, у педагогіці стала актуальним предметом дослідження низки науковців, 3-поміж них - Н. Асташової, І. Беха, О. Вишневського, І. Зязюна, П. Ігнатенка, В. Кузнецової, Т. Левченко, В. Лутая, В. Сластьоніна, В. Струманського, О. Сухомлинської.

Вивчення наукової літератури й ознайомлення 3 передовим педагогічним досвідом підтверджують нерозривність професійної підготовки компетентних фахівців 3 питанням про іiі ціннісне наповнення. Зумовлюється це тим фактом, що наявність професійних цінностей забезпечує відповідальне ставлення до майбутньої професійної діяльності, спонукає людину до творчого пошуку, удосконалює у свідомості студента «умовну» модель майбутньої

${ }^{1}$ Освіта України : нормативно-правові документи : До II Всеукраїнського з’їзду працівників освіти / гол. ред. кол. В.Г. Кремень. Київ : Міленіум, 2001. 472 с.

${ }^{2}$ Проект Концепції розвитку освіти до 2025 року. URL: https://eenu.edu.ua/ uk/articles/prezentovano-proekt-koncepciyi-rozvitku-osviti-do-2025-roku. 
професійної діяльності та слугує орієнтиром у професійному самозростанні.

\section{1. Зміст концептів «цінності» й «ціннісні оріснтації»: філософський, психологічний, соціально-педагогічний вимір}

Провідні вчені: I. Бех, М. Боришевський, Т. Бутківська, П. Ігнатенко, Т. Левченко, О. Сухомлинська - розглядають ціннісний підхід як найпріоритетнішу освітню проблему, оскільки проблема цінностей та ідеалів сьогодні виступає на перший план гуманітарних і соціальних наук, теорії й практики виховання ${ }^{3},{ }^{4}$. Ідею ціннісного підходу пов'язують із гуманістичною парадигмою освіти, реалізація якої передбачає звернення до моральних загальнолюдських цінностей i ïx відтворення в нових поколіннях. Тому особливої актуальності набуває питання визначення, усвідомлення та класифікації справжніх моральних цінностей і норм, які визначають сенс життя, з одного боку, і поєднують суспільство й особистість - $з$ іншого.

Проте для категорійного обгрунтування вихідних педагогічних понять і побудови їх системи необхідним є звернення до філософських та аксіологічних концепцій, що підкреслюють дослідники (С. Гессен, В. Доній, Г. Заїченко, О. Сухомлинська). Філософські поняття й категорії $\epsilon$ призмою, крізь яку людина сприймає навколишній світ, тому вміння користуватися філософськими поняттями, зокрема, для визначення цінностей $€$ важливою основою успішної теоретичної й практичної діяльності ${ }^{5}$.

Аналіз сучасної філософської літератури переконує в тому, що цінність $є$ складним комплексним утворенням, яке міститься в пізнавальних структурах, процесах соціального життя й культури, світогляді людини. Як стверджує С. Гессен, «навіть найбільш часткові й конкретні питання педагогіки належать в основних своїх засадах до суто філософських проблем» ${ }^{6}$. Отже, педагогіка звертається до доробку філософії як пізнання універсальних смислів та еталонів людської діяльності, суспільствознавчих, гуманітарних наук як до методологічного базису в дослідженні проблем ціннісних орієнтацій.

Поняття «цінність», уведене послідовниками I. Канта Р.Г. Лотце й Г. Коген, з'явилося в науковій літературі в 60 -х роках XIX століття, саме тоді

\footnotetext{
${ }^{3}$ Ігнатенко П.Р. Аксіологія виховання: від термінології до постановки проблеми. Педагогіка і психологія. 1997. № 1. С. 118-123.

${ }^{4}$ Жерносек І.П. Деякі ціннісні орієнтації молоді. Цінності освіти і виховання : наук.-метод. зб. / за заг. ред. О.В. Сухомлинської та ін. Київ, 1997. С. 39-41.

5 Желуденко М.О. Різні підходи до визначення цінностей в аксіологічних теоріях. Теоретичні питання культури, освіти та виховання. 2004. Вип. 26. С. 30-33.

${ }^{6}$ Гессен С.И. Основы педагогики. Москва : Школа-Пресс, 1995. 447 с.
} 
стан розвитку гуманітарної, педагогічної, філософської думки вимагав детального обгрунтування цього поняття, ураховуючи його специфіку в різних галузях; відповідно, з'явилася нова філософська галузь - аксіологія. Сам термін «цінність» почали вживати в літературі в позитивному, негативному та нульовому значеннях відповідно до логіки оцінок, адже визначення цінності відбувається шляхом співвіднесення об'єкта 3 певним зразком (ідеалом, еталоном, нормою), а також за допомогою встановлення міри відповідності цьому зразку. Зміст понять «цінності» й «ціннісні орієнтації» досліджувався у філософському, психологічному, педагогічному аспектах як вітчизняними (I. Бех, Т. Бутківська, О. Вишневський, Л. Вовк, А. Срмоленко, О. Здравомислов, М. Каган, Т. Левченко, О. Сухомлинська), так і зарубіжними (І. Кант, М. Маслоу, Г. Мюнстерберг, Ф. Ніцше, Е. Фромм, А. Шопенгауер, К.Г. Юнг) дослідниками.

На початку XX століття проблема дослідження «цінностей» набула особливого значення та важливості й стала центром уваги багатьох дослідників різних країн (М. Вебер, В. Віндельбанд, М. Гайдеггер, Е Гуссерль, В. Дильтей, Г. Мюнстерберг, Г. Риккерт, М. Шелер, О. Шпенглер). Ця зосередженість зумовлена зміною ціннісних пріоритетів усього людства, формуванням нової системи цінностей (Е. Трельч).

У середині XX століття 3'являється потреба переоцінки цінностей шляхом змін у свідомості. М. Каган визначає такі причини зміни свідомості: усвідомлення кризи культури та суспільного буття, перехід від індустріального суспільства до постіндустріального, модернізму до постмодернізму, вплив технологічних змін на цінності. Проблематика концепту «цінностей» набуває міжнародного виміру (М. Блек, К. Боулдинг, Х. Гадамер, П. Лоренц, Р. Мак Кеон, А. Маслоу, М. Моритц, Ш. Перельман, Ф. Фукуям) ${ }^{7}$.

XXI століття акцентує увагу на правах i свободах особистості, гуманістичному світогляді, відповідальному ставленні до діяльності й довкілля.

Як засвідчив аналіз джерельної бази наукової розвідки, застосування різних підходів до визначення самого поняття «цінності» спричинили складність і суперечливість означеної проблеми. В. Тюрина та Е. Научитель дають узагальнене визначення і трактують цінність як сукупність усіх значущих, ціннісних і важливих для людини елементів. К. Клакхон і П. Вільямс ототожнюють цінність із такими поняттями, як стандарт, критерій, судження, вибір, оцінювання.

${ }^{7}$ Каган М.С. Философская теория ценности. Санкт-Петербург : Петрополис, 1997. 205 c. 
Існують й інші визначення цінності, наприклад, як уявлення, думка. Так, М. Рокіч уважає, що «цінність - це абстрактні ідеї, позитивні чи негативні, не пов'язані з певним об'єктом або ситуацією, що відбивають людські переконання щодо типів поведінки та переважаючих цілей». Іншої точки зору дотримуються В. Ядов і його послідовники, вони акцентують увагу на психологічному аспекті індивідуальних цінностей як різновиді соціальних установок чи інтересів. М. Лапін та О. Леонтьєв визначають цінності як утворення, що допомагають здійснити вибір поведінки та забезпечують інтеграцію особистості в суспільство ${ }^{8}, 9$.

I. Жерносек дає своє визначення поняттю «цінність» - відособлені в ході розвитку історії інтереси, об'єктом яких є духовний зміст. Цінність формує інтереси групи, суспільства, людства та надає їм відповідної форми й цілеспрямованості. Він виділяє компоненти зв'язку між інтересами людей і цінностями: система розподілу праці, особисті стосунки, визнання чи невизнання тієї чи іншої цінності $з$ погляду конкретної релігії чи ідеології. Різні підходи до визначення цінностей дослідник зводить до таких груп: 1) цінності як сукупність матеріальних і духовних об'єктів, здатних задовольнити потребу, бажання, інтереси, цілі суб'єкта; 2) цінності, що відображають характер взаємовідношень між об'єктами; 3) цінності як узагальнені уявлення про блага, яким надається перевага; 4) цінності як специфічне явище свідомості, образ поведінки, діяльності, спілкування в різних сферах життя ${ }^{10}$.

За В. Тюриною, цінностями $є$ ідеї, дійсні або уявні предмети, стосовно яких індивіди або соціальні групи відчувають повагу, яким приписують важливу роль у своєму житті, а прагнення досягти їх відчувають та оцінюють як необхідність, обов'язок. Цінностями $\epsilon$ предмети, явища, стани, які забезпечують індивідові чи групі почуття вдоволення, психічну рівновагу, а прагнення їх досягти чи потяг до них дають почуття виконаного обов'язку. Цінності забезпечують також внутрішню солідарність групи, їі силу та значущість серед інших груп.

Цінності можуть бути також елементом моральної свідомості, яка разом із моральною діяльністю й моральними відносинами утворюють структуру моралі як соціального явища, а завдяки моральним нормам набувають олюдненої форми. Вони стають ближчими до реального

${ }^{8}$ Ігнатенко П.Р. Аксіологія виховання: від термінології до постановки проблеми. Педагогіка і психологія. 1997. № 1. С. 118-123.

9 Желуденко М.О. Цінності освіти і виховання у педагогічних системах Німеччини та України : дис ... канд. пед. наук : 13.00.01. Київ, 2006. 226 с.

10 Сухомлинська О.В. Проблеми теорії виховання дітей і молоді України. Педагогіка і психологія. 1997. № 4. С. 109-125. 
життя та дають можливість людині наблизитися до загальних морально-духовних цінностей, як стверджує В. Малахов, лише через зв'язки 3 ближнім ${ }^{11}$. Отже, цінності, засвоєння яких відбувається протягом усього життя, $є$ важливим чинником соціальної регуляції поведінки особистості та взаємин людей. За Е. Фроммом, визначити їх можна, ураховуючи індивідуальні інтереси особистості й затрачені людиною власні сили.

Виходячи із цього, можна виділити два підходи до визначення цінностей: цінності, значущість яких визначається наявними потребами людей, з одного боку, і цінності, які самостійно надають сенсу людському існуванню, з іншого боку.

Залежно від світоглядного вибору виділяють ще два типи цінностей, основою виникнення яких $\epsilon$ теоретично-світоглядне протистояння альтернативних підходів до самої сутності моральності. До першого з них належать цінності, що мають універсальний характер для всього людства, це загальновизнані загальнолюдські цінності етико-гуманістичного спрямування (Ю. Габермас, Є. Дюринг, Г. Йонас, Г. Мюнстерберг, Е. Фромм, А. Швейцер, А. Єрмоленко, О. Забужко, В. Малахов). Другий тип становлять цінності локальної спільноти, до якої належить індивід. Це такі цінності, які акцентують увагу на національному, культурному, земельному самоутвердженні й утілюються в ідеях комунітаризму (М. Волзер, Е. Макінтайр, М. Сендел).

Більшість дослідників теорії цінностей сходяться в тому, що перевагу варто надавати універсальним загальнолюдським цінностям. Ядро загальнолюдських цінностей становлять базові цінності прагнення до істини, творчості, краси, орієнтація на добро, честь і гідність. Вищі, ідеально мислимі трансцендентні цінності, що є історично складеними модусами, способом зв'язку свідомості й буття, людини й світу, становлять основу життєдіяльності. Загальнолюдські цінності передбачають також поважне ставлення до різноманітності проявів людського життя й духовності. Під кутом локальних спільнот і цінностей мається на увазі сприяння розвитку кожної нації та культури, оскільки вони є часткою загального людського досвіду. В. Малахов, внесок якого в розроблення вітчизняної теорії цінностей $\epsilon$ надзвичайно великим, у контексті сучасних моральних проблем говорив: «Неможливо бути людиною моральною, нехтуючи моральними цінностями власної культури й не поважаючи особливість

${ }^{11}$ Євтух М.Б., Потапенко К.К. Виховний ідеал як основна гуманістична цінність. Цінності освіти і виховання : наук.-метод. зб. / за заг. ред. О.В. Сухомлинської та ін. Київ, 1997. С. 109-113. 
ціннісного світу представників інших людських спільнот» ${ }^{12}$. У такий спосіб він розкриває моральний принцип взаємності, доводячи, що цінності власної спільноти певною мірою є частиною універсальних цінностей, оскільки, розвиваючись духовно, будь-яка нація виявляє повагу до цінностей інших народів. Це стосується кожної нації, зокрема української, яка не була б такою багатою культурними, національними, історичними традиціями й не мала б таку варіативність національних духовних цінностей, якщо не розвивалася б і не збагачувалася завдяки іншим культурам - російській, білоруській, польській. Ще Й. Фіхте наполягав на тому, що будь-який народ або окремі його представники, які займаються механічним запозиченням чужих духовних цінностей, типів мислення, втрачають здатність створювати щось нове в рамках і рідної, і чужої для себе культури ${ }^{13}$.

Говорячи про систему українських національних цінностей і норм, В. Малахов виділяв емоційність, душевність, індивідуалізм, заснований на православній інтровертованості, динамізм, вільнолюбство, прагнення до внутрішньої гармонії ${ }^{14}$.

Т. Бутківська поділяє всі цінності на дві групи - сутнісно-життєві та універсальні. Під сутнісно-життєвими маються на увазі уявлення про добро і зло, щастя, мету й сенс життя. Універсальні поділяються на такі підгрупи: вітальні (життя, здоров'я, особиста безпека, добробут, сім'я, родичі, освіта), суспільного визначення (працелюбство, соціальний статус), міжособистісного визначення (чесність, альтруїзм, доброзичливість), демократичні (свобода слова, совісті, національний суверенітет). За іншою класифікацією цінності поділяються на партикулярні (належність до малої батьківщини, сім’ї) та трансцендентні (віра в Бога, прагнення до абсолюту) ${ }^{15}$.

За О. Вишневським, цінності поділяються на п'ять груп: 1) абсолютні (доброта, чесність, любов, справедливість, гідність, мудрість, свобода, правда, віра, надія, милосердя); 2) національні (патріотизм, готовність до захисту Батьківщини, почуття національної гідності, державотворчі прагнення, історична пам'ять, прагнення до

12 Малахов В.А. Етика : курс лекцій. Острог : Видавництво Національного університету «Острозька академія», 2014. 214 с.

${ }^{13}$ Кант И., Гегель Г.В.Ф., Шеллинг Ф.В.И. Немецкая классическая философия. Харьков, 2000. Т. 1 : Право и свобода. 784 с.

${ }^{14}$ Фролова Н.В. Трансформація системи ціннісних орієнтацій на зламних етапах розвитку суспільства (психологічний аспект) : автореф. дис. ... канд. пед. наук : 09.00.01. Київ, 1998. 18 с.

15 Бутківська Т.В. Проблеми цінностей у соціалізації особистості. Цінності освіти і виховання : наук.-метод. зб. / за заг. ред. О.В. Сухомлинської. Київ, 1997. C. 27-31. 
національної єдності, любов до рідної культури, мови, збереження національних свят, традицій, увага до зміцнення здоров'я громадян); 3) громадські (свобода людини, рівність усіх людей, визнання принципів демократії, ідея соціальної гармонії, обов'язки перед іншими людьми, повага до законів); 4) сімейні (моральні основи існування сім’ї, оберігання пам'яті предків, збереження сімейних традицій); 5) особистого життя (внутрішня свобода, почуття власної гідності, воля, самоконтроль, самодисципліна, енергійність, мудрість, розум, здоровий глузд, мужність, рішучість, зовнішньо-етична вихованість, щедрість, повноцінна самореалізація, розвиток творчого потенціалу, естетичних смаків, турбота про охорону довкілля) ${ }^{16}$.

М. Боришевський також розробив класифікацію цінностей, у якій на першому місці знаходяться моральні цінності. Вони спрямовані на гуманізацію міжособистісних стосунків - доброта, справедливість, щирість, толерантність, взаємоповага, відповідальність, принциповість, працелюбство ${ }^{17}$.

Останніми роками дуже помітними в суспільстві стали зміни ціннісної свідомості загалом і студентства як складника суспільства. Спостерігається загальна тенденція переходу від колективістської до індивідуалістської системи цінностей. Перевага в системі ціннісних орієнтацій надається поєднанню особистісних (щастя, любов, внутрішня гармонія, наявність добрих друзів) і суспільних цінностей (зростання професійної кар'єри, професійна саморегуляція). Результатом трансформацій i змін у суспільстві $€$ проголошення свободи, упевненості в собі, активного діяльного життя найвищими цінностями, тоді як колективістська цінність «щастя інших» належить до найменш значущих.

Цінності $€$ найвищими авторитетами, орієнтаціями, без яких неможливо досягти етичного прогресу, толерантності. Саме тому для правильного виховання молоді надзвичайно важливим $\epsilon$ вивчення цінностей $\mathrm{i}$ ціннісних орієнтацій $\mathrm{i}$ ï аналіз під час побудови педагогічного процесу, орієнтація на гуманізм і загальнолюдські «вічні» цінності, які «живуть», незважаючи на процес девальвації багатьох інших цінностей, урахування суспільного та особистісного аспекту цінностей. Окрім того, природу людини в іiі емоційнопсихічних проявах можна зрозуміти через розуміння природи

16 Вишневський О.І. Система цінностей і стратегія виховання. Рідна школа. 1997. № 7-8. С. 3-5.

${ }^{17}$ Боришевський М.Й. Духовність особистості: соціально-психологічна сутність, детермінанти становлення та розвитку. Проблеми загальної та педагогічної психології. Київ, 2007. Т. ІХ. Ч. 5. 524 с. 
гуманістичних цінностей і ціннісних орієнтацій. А щоб «довіряти» цінностям, за словами Е. Фромма, людина має передусім пізнати себе, це знання дає усвідомлення того факту, що джерелом усіх моральних норм $є$ людина. Саме тому одними 3 найвищих цінностей у різних педагогічних системах $\epsilon$ особистість, повага до людського життя, самореалізація $^{18}$.

3 поняттям «цінність» тісно пов'язана категорія ціннісних орієнтацій, причини виникнення якої, механізми формування та їх взаємодія впливають на загальний рівень особистісного розвитку. Ціннісні орієнтації, за А. Анненковим, $є$ «тими компонентами структури особистості, у яких ніби концентрується весь життєвий досвід, накопичений особистістю в ії індивідуальному розвитку; це той елемент структури особистості, який являє собою вісь свідомості, навколо якої вирішується багато життєвих питань» 19 . Ціннісні орієнтації відображають значущість предметів чи соціальних явищ для особистості. Вони є домінантним мотивом поведінки в повсякденному житті та структурним компонентом особистості, завдяки якому можна виявити загальні соціальні пріоритети й мотиви поведінки.

Н. Фролова до факторів, які впливають на формування системи ціннісних орієнтацій, зараховує також сімейне оточення й сімейні традиції, доступ до засобів освіти й культурних досягнень людства, релігійні переконання та «внутрішні умови», що формують індивідуальну картину світу ${ }^{20}$.

Проаналізувавши праці багатьох дослідників, можна виділити основні причини трансформації ціннісних орієнтацій: соціальноекономічні зміни суспільства, які призводять до зміни моральних норм поведінки, мікро- та макрооточення, міжособистісний вплив, система виховання, вікові, індивідуальні, психологічні особливості, ступінь самореалізації та саморозвитку, професійна спрямованість, матеріальний стан, участь у суспільному житті ${ }^{21}$.

Складна природа цінностей і ціннісних орієнтацій є основою для різних класифікацій, що відображають відповідні теоретичні погляди,

${ }^{18}$ Фромм Э. Быть или иметь. URL: http://psylib.org.ua/books/fromm02/index.htm.

19 Желуденко М.О. Цінності освіти і виховання у педагогічних системах Німеччини та України : дис. ... канд. пед. наук : 13.00.01. Київ, 2006. 226 с.

${ }^{20}$ Фролова Н.В. Трансформація системи ціннісних орієнтацій на зламних етапах розвитку суспільства (психологічний аспект) : автореф. дис. ... канд. пед. наук : 09.00.01. Київ, 1998. 18 с.

21 Желуденко М.О. Різні підходи до визначення причин девальвації системи загальних моральних цінностей у педагогічній системі Німеччини. Наука $i$ сучасність : збірник наукових праць Національного педагогічного університету імені М.П. Драгоманова. 2003. Том XL. C. 43-50. 
яких дотримуються автори цих класифікацій (Т. Бутківська, I. Ващенко, П. Ігнатенко, М. Лапін, Н. Петрунівська, М. Рокіч, В. Ядов). Але єдину універсальну класифікацію виділити неможливо 3 огляду на численність підходів до означеної проблеми. Наприклад, П. Ігнатенко класифікує ціннісні орієнтації за такими принципами: за об'єктом споживання - матеріальні, морально-духовні; за метою споживання - егоїстичні, альтруїстичні; за рівнем узагальненості конкретні, абстрактні; за родом діяльності - термінальні, інструментальні; за змістом діяльності - пізнавальні, предметноперетворювальні; за належністю - особистісні, групові, колективні, суспільні, національні, загальнолюдські ${ }^{22}$.

Ціннісні орієнтації $\epsilon$ відображенням соціально-економічних змін суспільства у свідомості особистості під впливом індивідуального досвіду та особистісних факторів: належністю до певної соціальної групи, вікових особливостей, матеріального стану, професійної орієнтації. Вони мають водночас соціогенний характер, оскільки провідними компонентами суспільної системи цінностей є моральні й культурні норми, естетичні ідеали, політичні й правові принципи, філософські та релігійні ідеї.

Прищеплення цінностей i формування аксіологічного світогляду відбувається саме в процесі навчання й виховання, тому важливим педагогічним завданням є вибір оптимальних та ефективних шляхів, які на основі ціннісного підходу сприяють розвитку розвиненої моральної особистості.

\section{2. Сутність і роль професійних цінностей у формуванні майбутнього фахівця}

Проблема професійних цінностей розглядається науковцями під різними кутами, однак особливо актуальним постає іï вивчення в контексті дослідження різних аспектів професійної підготовки, професійної самореалізації, формування професіоналізму, дослідження кар'єри та інших складників професійного життя особистості (Б. Ананьєв, К. Абульханова-Славська, Л. Анциферова, О. Асмолов, М. Боришевський, Б. Братусь, Л. Виготський, Г. Костюк, О. Леонтьєв, С. Максименко, С. Рубінштейн, Т. Титаренко, Л. Сохань).

Аналіз сучасної наукової літератури дав змогу зробити висновок про значні трансформації в структурі особистісної спрямованості серед сучасної молоді як найбільш мобільного сегменту суспільства:

${ }^{22}$ Меньшиков В.М. Педагогика Эразма Роттердамского: открытие мира детства. Педагогическая система Хуана Луиса Вивеса : учебное пособие. Москва : Народное образование, $1995.136 \mathrm{c.}$ 
відбувається формування нового покоління, яке має своє ставлення до проблеми професійного зростання.

У секторі вищої професійної освіти усвідомлення студентом цінності об'єкта професійної дійсності формує особливий вид ставлення до нього - це ціннісне ставлення до своєї майбутньої професійної діяльності. У рамках аксіологічного підходу кожен учасник освітнього процесу визнається активним ціннісномотивованим суб'єктом діяльності, розглядається як суб'єкт пізнання, спілкування і творчості ${ }^{23}$.

Проаналізувавши науковий доробок багатьох учених, можемо виділити чинники, які впливають на професійний вибір майбутньої професії молодої людини, - зовнішні та внутрішні чинники. Їх трактують як основу, що впливає на будь-який процес, змінюючи його ступінь і характер, розкриваючи динаміку його продуктивності.

Зовнішні чинники (соціальні) пов'язані з впливом навколишнього середовища: судженням батьків, друзів, ровесників, бажанням досягнути зовнішнього успіху або з певними сумнівами, побоюваннями осуду тощо. До зовнішніх чинників ми зараховуємо політичні аспекти розвитку суспільства; соціально-економічні умови; соціальне середовище; ринковий попит на кадри певної професії; вимоги ринку праці до особистості як до фахівця, а також до стану його здоров'я, психофізіологічних властивостей і психологічних якостей; доступність освіти (обмеження у виборі кількості професій тими учнями, які проживають у сільській місцевості чи невеличкому містечку); професійно-освітні вимоги (спеціальні вміння та знання, відповідний досвід їх застосування для вирішення професійних завдань у певній галузі народного господарства); перспективи професійного зростання, кар'єри, підвищення кваліфікації; особливості професії, яка обирається (умови праці, оплати, престиж, імідж професії в суспільстві тощо).

Внутрішні (психологічні) чинники, які притаманні конкретній людині, визначають особистісні здібності, нахили, звички, характер тощо. До внутрішніх чинників ми зараховуємо мотивацію вибору професії (орієнтація на життєві цінності, уявлення про майбутнє, досвід тощо); усвідомленість соціальної та особистої значущості професії; зацікавленість (пізнавальний, професійний інтерес, схильності); уроджені задатки (здібності як психологічні механізми, необхідні для успіху в професійній діяльності); темперамент і характер; профорієнтацію (інформованість про світ професій).

${ }^{23}$ Гринюк С. Освітня гібридизація як інструмент модернізації освітньої галузі. Актуальні проблеми сучасної науки : матеріали наук.-практ. конф. (Київ, 30-31 травня 2019 р.). Київ, 2019. С. 37-42. 
У світлі нашої проблематики доречним уважаємо звернутися до визначень самого концепту «професійні цінності», запропонованих низкою науковців-дослідників. Отже, А. Позднякова трактує професійні цінності як похідні від загальнолюдських, групових та особистих цінностей ${ }^{24}$. За ii теорією, загальнолюдські цінності й цінності будь-якого соціуму формуються в людини родиною, школою, у процесі стихійної соціалізації, а професійні цінності - у ході навчання за професією та сумлінної професійної діяльності.

В. Мальцев уважає, що професійні цінності - це орієнтація особистості на професійну діяльність та усвідомлення іiі значущості зпоміж інших видів діяльності ${ }^{25}$. В. Сластьонін, у свою чергу, виокремлює поняття «професійно-ціннісні орієнтації», які трактує як систему стійких вибіркових відносин фахівця до найбільш значущих аспектів професійної діяльності, що формуються на основі широкого спектру всіх духовних відносин особистості.

Узагальнюючи викладене вище, можемо стверджувати, що під професійними цінностями варто розуміти предмети, явища та їх властивості, які необхідні суспільству й особистості як засоби задоволення особистих і соціальних потреб. Вони формуються в процесі засвоєння особистістю суспільного досвіду й відображаються в iii цілях, переконаннях, ідеалах та інтересах. Крім того, можливим видається позиціонувати професійні цінності як стратегічні цілі, які спонукають людей до сумісної мети, тим самим визначаючи значущість для майбутнього фахівця вміти орієнтуватися в них. Звідси завданням вищого навчального закладу стає створення оптимальних умов для формування професійних цінностей майбутніх фахівців ${ }^{26}$.

М. Тітм у ставленні до професійної діяльності визначає такі цінності: цінності професії, що пов'язані 3 самовизначенням у професійній діяльності; цінності професії, що виникають на основі різних видів винагороди професійної діяльності з боку суспільства; цінності, що утворюються на базі різних рис тієї чи іншої професії; цінності вищого гатунку, що використовуються в суспільстві для регуляції ставлення до професії.

24 Позднякова А.Л. Формирование ценностного отношения будущего специалиста к профессиональной деятельности (на примере подготовки экономистов) : дисс. ... канд. пед. наук : 13.00.08. Чита, 2011. 323 с.

25 Мальцев В.А. Формирование, развитие и функционирование системы личностных смыслов в процессе вузовского обучения. URL: http://hpsy.ru/ public/x2492.htm.

${ }^{26}$ Grynyuk S. The basics of education for sustainable development. Збірник наукових праць. Серія «Педагогічні науки». 2018. Вип. LXXXII. Том 3. С. 9-12. 
На думку Є. Клімова, професійно-важливі якості є похідними від моральних якостей особистості й ієрархії іiі системи цінностей. В. Оссовський під професійними цінностями розуміє значущість професійної діяльності для суспільства й особистості, а також значущість різних сторін професійної діяльності, до яких у суб'єкта формується певне ставлення ${ }^{27}$.

У цьому контексті певний сенс має класифікація професійних цінностей педагога, розроблена Й. Ісаєвим. Виходячи 3 типології професійних цінностей Й. Ісаєва, можна виділити цінності-цілі, цінності-ставлення, цінності-знання, цінності-уміння й цінності-якості. Як зазначає в дослідженні Н. Шемигон, очевидним є взаємозв'язок між групами цінностей: цінності-цілі визначають характер цінностей-знань і цінностей-умінь, цінності-ставлення залежать від цінностей-цілей і цінностей якостей тощо ${ }^{28}$.

У зрізі досліджуваного питання низка науковців в основу класифікації професійних цінностей закладає соціальний аспект, намагаючись уписати професійну діяльність у структуру соціуму й соціальних відносин. При цьому виділяють суспільно-професійні, професійно-групові й особистісно-професійні цінності. Суспільнопрофесійні цінності відображають характер і зміст цінностей, що функціонують у різних соціальних системах, виявляються в суспільній свідомості у формі моралі, релігії, філософії. Це ідеї, уявлення, норми й правила регламентують професійну діяльність і спілкування в межах усього суспільства. Професійно-групові цінності $\epsilon$ сукупністю ідей, концепцій, норм, які регламентують і спрямовують професійну діяльність у межах відповідних професійних інститутів.

Досліджуючи проблеми формування професійної свідомості студентів, С. Лєвшин виявив декілька груп цінностей, пов'язаних із професійною діяльністю та значущих для студентів 3 погляду майбутньої реалізації в професії: цінності, пов'язані із самоствердженням у суспільстві, найближчому соціальному середовищі (суспільна значущість праці, престиж професійної діяльності, визнання рідних, близьких, знайомих тощо); цінності, пов'язані із задоволенням потреби в спілкуванні (постійна робота з людьми, можливість спілкування з різними людьми тощо); цінності, пов'язані із самовдосконаленням (творчий і різноманітний характер

${ }^{27}$ Grynyuk S. In the era of global English market. Наукові записки Острозькоі академії. 2015. № 55. С. 234-237.

28 Шемигон Н.Ю. Формування ціннісних орієнтацій майбутніх педагогів у процесі професійної підготовки : автореф. дис. ... канд. пед. наук : 13.00.04. Харків, 2008. 21 с. 
праці, можливість постійно займатися улюбленою справою, постійно оновлювати свої знання тощо); цінності, пов'язані із самовираженням (зацікавленість діяльністю, можливість впливати на людей, відповідність діяльності здібностям тощо); цінності, пов'язані 3 утилітарно-прагматичними запитами особистості (гарний заробіток, можливість просування по службі тощо) ${ }^{29}$.

На думку науковця, частина цих цінностей виникає в процесі оволодіння професією й осмислення майбутньої професійної діяльності, решта - у процесі набуття практичних навичок діяльності в реальних умовах.

О. Горбенко, досліджуючи проблему формування професійних цінностей майбутніх фахівців, зауважує, що «особистісні професійні цінності кожного фахівця повинні відповідати прогресивним суспільним цінностям, визначати специфічні групові цінності у світі професії, відображати внутрішній світ, індивідуальні життєві цілі, ідеали, якості людини як унікальної особистості» ${ }^{30}$. Саме тому, на думку дослідниці, в основу індивідуальних варіантів персональних цінностей майбутніх фахівців певного профілю необхідно вносити систему загальних суспільних цінностей.

Формування системи ціннісних орієнтацій відбувається комплексно й поетапно в ході набуття особистістю відповідних предметних компетентностей як результату громадянської, правової, філософської, економічної освіти. Варто зауважити, що процес оволодіння цінностями та формування ціннісних орієнтацій майбутніх фахівців у навчально-виховному процесі $\epsilon$ можливим за умови виявлення і створення викладачем таких психолого-педагогічних умов, за яких цінності набувають цілісного, значущого, системного характеру й чинять регуляторний вплив на самостійність особистості студента ${ }^{31}$.

3 огляду на прагматично-практичний бік питання, багато студентів вищих закладів освіти, за результатами опитувань, зазначають, що цінують в одержуваній освіті не стільки можливість набуття (оволодіння) конкретної професії, скільки ті знання та практичні навички, які забезпечать їм можливість бути мобільними на ринку праці та знаходити роботу, яка відповідає їхнім цінностям і запитам. Вибір професійної освіти перестає бути пов'язаним із майбутньою

29 Левшин С.В. Формирование профессионального самосознания студентов как фактор успешной адаптации в профессии : дисс. ... канд. пед. наук : 13.00.08. Омск, 2011. $215 \mathrm{c}$.

${ }^{30}$ Жерносек І.П. Деякі ціннісні орієнтації молоді. Цінності освіти і виховання : наук.-метод. зб. / за заг. ред. О.В. Сухомлинської та ін. Київ, 1997. С. 39-41.

${ }^{31}$ Grynyuk S. The basics of education for sustainable development. Збірник наукових праць. Серія «Педагогічні науки». 2018. Вип. LXXXII. Том 3. C. 9-12. 
професією. Орієнтація багатьох випускників загальноосвітніх шкіл пов'язана не стільки з бажанням одержати конкретну професію і знайти відповідне їй місце майбутньої зайнятості, скільки 3 усвідомленням необхідності одержання гідного документа про повну середню освіту. Отже, чітко простежується орієнтація на цінності, які забезпечують можливість досягнення особистісних життєвих успіхів, тоді як цінності, що відображають орієнтацію на взаємодію з іншими людьми (готовність допомогти, толерантність, дружелюбність тощо), відходять на другий план.

I все ж таки погоджуємося 3 думкою, що професійна сфера $\epsilon$ найважливішим чинником самореалізації особистості в соціумі незалежно від того, які загальні ціннісні орієнтації в суспільстві обирає особистість і як ця «конкретна особистість» їх поділяє й виражає.

\section{ВИСНОВКИ}

Складність природи цінностей визначила різні підходи до їх розуміння, до цього часу не існує однозначного визначення самого поняття «цінність». Цінність характеризують як об’єктивну сутність речей, як власне цінність, як корисне для людини благо. Цінність пов'язують із суб'єктивною значущістю певного предмета для життедіяльності людини, з їі властивостями задовольняти потреби, інтереси, бажання.

У реальному соціальному бутті розмаїття цінностей виявляється в тому, що більші або менші соціальні групи, економічні класи, політичні партії, релігійні конфесії, етнічні та національні спільноти мають свої цінності й норми. Кожна історична епоха проголошує певні цінності найвищими.

Ціннісні орієнтації формуються в процесі діяльності та спілкування. Джерелом ціннісних орієнтацій $є$ активність особистості, яка визначає iï орієнтацію на досягнення конкретних цілей. Ціннісні орієнтації $\epsilon$ відображенням соціально-економічних змін суспільства у свідомості особистості під впливом індивідуального досвіду й особистісних факторів: належність до певної соціальної групи, вікові особливості, матеріальний стан, професійна орієнтація.

Становлення майбутнього фахівця на етапі його навчання у вищому навчальному закладі має бути підпорядковано меті - «забезпечення достатньо надійної поведінки індивіда в конкретних типових життєвих і професійних умовах», що дає змогу сформувати професійні цінності в студентів i стійких рис їхньої особистості, характерних для майбутнього виду діяльності. Системно-ціннісний підхід у процесі підготовки майбутніх фахівців являє собою вищий прояв людської освіченості та його професійної компетентності. 


\section{АНОТАЦІЯ}

У статті актуалізовано проблему аксіологічного підходу до формування професійної компетентності майбутніх фахівців. Визначено сутність феноменів «цінність», «ціннісні орієнтації», «професійні цінності». Висвітлено підходи науковців до класифікації цінностей, ціннісних орієнтацій, професійних цінностей і їх впливу на професійне становлення майбутнього фахівця. Виявлено залежність системи професійних цінностей від соціально-економічних і політичних змін у суспільстві. Доведено, що становлення майбутнього фахівця на етапі його навчання у ЗВО має бути підпорядковано меті «забезпечення достатньо надійної поведінки індивіда в конкретних типових життєвих і професійних умовах». Такий підхід дасть змогу сформувати професійні цінності в студентів і стійких рис їхньої особистості, характерних для майбутнього виду діяльності. Висловлюється думка: лише на рівні професійно-особистісної культури може повною мірою розкритися людська індивідуальність фахівця.

\section{ЛIТЕРАТУРА}

1. Боришевський М.Й. Духовність особистості: соціальнопсихологічна сутність, детермінанти становлення та розвитку. Проблеми загальної та педагогічної психології. Київ, 2007. Т. ІХ. Ч. 5.524 с.

2. Виндельбанд В. О свободе воли. Минск, 2000. 208 с.

3. Вишневський О.І. Система цінностей і стратегія виховання. Рідна школа. 1997. № 7-8. С. 3-5.

4. Гессен С. И. Основы педагогики. Москва : Школа-Пресс, 1995. $447 \mathrm{c}$.

5. Гринюк С. Освітня гібридизація як інструмент модернізації освітньої галузі. Актуальні проблеми сучасної науки : матеріали наук.практ. конф. (Київ, 30-31 травня 2019 р.). Київ, 2019. С. 37-42.

6. Grynyuk S. In the era of global English market. Наукові записки Острозької академії. 2015. № 55. С. 234-237.

7. Grynyuk S. The basics of education for sustainable development. Збірник наукових пращь. Серія «Педагогічні науки». 2018. Вип. LXXXII. Том 3. С. 9-12.

8. Жерносек І.П. Деякі ціннісні орієнтації молоді. Цінності освіти $i$ виховання : наук.-метод. зб. / за заг. ред. О.В. Сухомлинської та ін. Київ, 1997. С. 39-41.

9. Желуденко М.О. Різні підходи до визначення причин девальвації системи загальних моральних цінностей у педагогічній системі Німеччини. Наука $i$ сучасність : збірник наукових праць Національного педагогічного університету імені М.П. Драгоманова. 2003. Том XL. C. 43-50. 
10. Желуденко М.О. Різні підходи до визначення цінностей в аксіологічних теоріях. Теоретичні питання культури, освіти та виховання. 2004. Вип. 26. С. 30-33.

11.Желуденко М.О. Цінності освіти і виховання у педагогічних системах Німеччини та України : дис. ... канд. пед. наук : 13.00.01. Київ, 2006. 226 с.

12. Ігнатенко П.Р. Аксіологія виховання: від термінології до постановки проблеми. Педагогіка і психологія. 1997. № 1. С. 118-123.

13. Каган М.С. Философская теория ценности. Санкт-Петербург : Петрополис, 1997. 205 с.

14. Левшин С.В. Формирование профессионального самосознания студентов как фактор успешной адаптации в профессии : дисс. ... канд. пед. наук : 13.00.08. Омск, 2011. 215 с.

15. Малахов В.А. Етика : курс лекцій. Острог : Видавництво Національного університету «Острозька академія», 2014. 214 с.

16. Мальцев В.А. Формирование, развитие и функционирование системы личностных смыслов в процессе вузовского обучения. URL: http://hpsy.ru/public/x2492.htm.

17. Меньшиков В.М. Педагогика Эразма Роттердамского: открытие мира детства. Педагогическая система Хуана Луиса Вивеса : учебное пособие. Москва : Народное образование, 1995. 136 с.

18. Освіта України : нормативно-правові документи: До II Bceукраїнського з'їзду працівників освіти / гол. ред. кол. В.Г. Кремень. Київ : Міленіум, 2001. 472 с.

19. Позднякова А.Л. Формирование ценностного отношения будущего специалиста к профессиональной деятельности (на примере подготовки экономистов) : дисс. ... канд. пед. наук : 13.00.08. Чита, 2011. $323 \mathrm{c}$.

20. Риккерт Г. Философия жизни. Киев : Ника-Центр, 1998. 512 с.

21. Сухомлинська О.В. Проблеми теорії виховання дітей і молоді України. Педагогіка і психологія. 1997. № 4. С. 109-125.

22. Кант И., Гегель Г.В.Ф., Шеллинг Ф.В.И. Немецкая классическая философия. Харьков, 2000. Т. 1 : Право и свобода. 784 с.

23. Проект Концепції розвитку освіти до 2025 року. URL: https://eenu.edu.ua/uk/articles/prezentovano-proekt-koncepciyi-rozvitkuosviti-do-2025-roku.

24. Свтух М.Б., Потапенко К.К. Виховний ідеал як основна гуманістична цінність. Цінності освіти і виховання : наук.-метод. зб. / за заг. ред. О.В. Сухомлинської та ін. Київ, 1997. С. 109-113.

25. Фролова Н.В. Трансформація системи ціннісних орієнтацій на зламних етапах розвитку суспільства (психологічний аспект) : автореф. дис. ... канд. пед. наук : 09.00.01. Київ, 1998. 18 с. 
26. Фромм Э. Быть или иметь. URL: http://psylib.org.ua/books/ fromm02/index.htm.

27. Шемигон Н.Ю. Формування ціннісних орієнтацій майбутніх педагогів у процесі професійної підготовки : автореф. дис. ... канд. пед. наук : 13.00.04. Харків, 2008. 21 с.

Information about the authors: Grynyuk S. P., Ph.D. in Pedagogic Sciences, Associate Professor of the Department of Linguistics and Social Communications

National Aviation University 1, L. Husara Av., Kyiv, Ukraine, 03055

Zheludenko M. O., Ph.D. in Pedagogic Sciences, Associate Professor of the Department of Linguistics and Social Communications

National Aviation University 1, L. Husara Av., Kyiv, Ukraine, 03055 